\title{
Terms Used in the Electricity Accounts
}

CAPACITY: As used here, nominal or nameplate rating of generators as of the end of the year indicated.

Gross production: Total output of power plants, including power used in station operations.

NET PRODUCTION: Output, excluding power used in station operation. Hydroelectricity: Power generated from falling water, including electricity produced by pumped storage plants (plants which generate power, usually during periods of peak demands, from water pumped into elevated reservoirs, usually during offpeak periods).

CONVENTIONAL THERMAL ELECTRICITY: Electricity generated in power plants using conventional fuels (commercial or non-commercial). This includes electricity generated in diesel and gas turbine plants as well as steam plants.

NUCLEAR ELECTRICITY: Electricity generated in power plants which derive their energy from nuclear fuels.

Geothermal electricity: Power generated from volcanic steam.

UTILITIES: Electricity supply systems operated primarily as suppliers of power for public use (as distinguished from industrial and transportation agencies generating primarily for their own use).

NET IMPORTS: Total imports minus total exports.

Gross SUPPLY: Gross production plus net imports.

NET SUPPLY (= gross consumption): Net production plus net imports.

Consumption: Net supply, excluding own use and loss; power delivered to consumers.

Transportation: Railways, tramways, trolleybuses, and subways.

INDUSTRY: Mining and manufacturing, including consumption in electric boilers. 
DOMESTIC SECTOR: Households, commercial establishments, public buildings and grounds, street lighting, and miscellaneous uses.

Loss (and use): Losses in transmission and distribution, plus the input of pumped storage plants. Where only gross production and supply figures are shown, includes also consumption by plant auxiliaries. 